\title{
Yaşlı onkoloji hastalarına bakım veren bireylerin yaşamında oluşan değişikliklerin belirlenmesi
}

\author{
Imatullah Akyar', Fatoş Korkmaz', Esra Atakul'2 \\ 1Hacettepe Üniversitesi Hemşirelik Fakültesi, Ankara \\ ${ }^{2}$ Sağlık Bil. Ü. Dr. Abdurrahman Yurtaslan Onkoloji Eğitim Araştırma Hastanesi, Ankara
}

\section{Öz}

Amaç: Yaşlıların bakım ve tedavisi, yaşlılık dönemine eşlik eden hastalık sayısındaki fazlalık, bu dönemde deneyimlenen semptomların yoğunluğu, yaşla orantılı fonksiyonel yeterlilikteki azalma, kişisel bakımda yaşanan sınırlılıklar ve tedavide takip edilen özel süreçler nedeniyle önemlidir. Bu araștırma, 65 yaș ve üzerinde kanser tanısı ile izlenen hastalara bakım veren bireylerin yaşamında, bakım verme nedeniyle oluşan değișikliklerin belirlenmesi amacıyla gerçekleştirilmiştir. Yöntem: Tanımlayıcı olarak gerçekleştirilen araştırmanın örneklemini kanser tanısı ile takip edilen 70 hastanın bakım verenleri oluşturmuştur. Örnekleme alınacak bakım veren sayısının hesaplanmasında güç analizi kullanılmıştır (\%80 güç, \%5 anlamlılık düzeyi, 0.50 etki büyüklügü̈). Veriler tanıtıcı bilgiler formu (23 soru) ve Bakas Bakım Verme Etki Ölçeği (puanı 15-105, yüksek puanlar olumlu yönde değişim) ile toplanmıştır. Araştırmada etik kurul izinleri ve çalışmaya katılan bakım verenlerden yazılı izin alınmıştır. Verilerin analizinde tanımlayıcı istatistikler, t testi, Kruskal Wallis ve Mann Whitney U testleri kullanılmıștır. Bulgular: Bakım verilen hastaların yaş ortalaması 73.1 \pm 7.2 (En düşük=63- En yüksek=92) ve \%55.7'si kadındır. Hastalar; en sık gastrointestinal sistem kanseri, lösemi tanısına ve ortalama $3.3 \pm 4.6$ aylık (En düşük=1 - En yüksek=36 ay) hastalık süresine sahiptir. Bakım verenlerin yaş ortalaması 51.3 \pm 11.9 (En düşük=24 - En yüksek=78), \%77.1'i kadın, \%87.1'i evli, \%50.0'ı bakım verdikleri hasta ile yaşamakta, \%61.4'ü hastanın çocuğu (\%24.3 kı, \%17.1 oğlu)'dur. Bakas Bakım Verme Etki Ölçeği ortalama puanı 51.7£8.9'dir. Bakım verenler "fiziksel sağlık, stresle başa çıkabilme yeteneği, arkadaşlarla olan ilişki, enerji düzeyi, duygusal iyilik hali, arkadaşlarla sosyal aktiviteler için zaman ve fiziksel işlevselliğim" maddelerinde olumsuz yönde diğer taraftan "hasta ile olan ilişki" maddesinde ise olumlu yönde değişim bildirmişlerdir. Sonuç: Çalışma sonucunda bakım vermenin, bakım verenin fiziksel ve psikolojik sağlığı üzerinde olumsuz etkiye ancak hasta ile sürdürülen ilişki üzerinde olumlu etkiye sahip olduğu ortaya çıkmıştır. Çalışmada ayrıca hastanın kanser tipi, cinsiyeti, yaşı (ileri yaş), eğitim düzeyi ve bakım verenin yaşı, eğitim düzeyi, çalışma durumu ve hasta ile yakınlık derecesinin bakım verme sürecinde olumsuz yaşantı değişikliğine yol açtığı ortaya konmuştur.

Anahtar Sözcükler: Bakım veren, yaşlı onkoloji, bakım vermeden etkilenme

Yazının geliş tarihi:20.04.2017

Yazının kabul tarihi:17.08.2017

SorumluYazar: YrdDoç.Dr. Imatullah Akyar, Hacettepe Üniversitesi Hemşirelik Fakültesi, Ankara, Türkiye.

E-posta: akyarim@gmail.com, akyar@hacettepe.edu.tr, Tel : +90 312305 15 80- 173

Çalışma STTI 44thBiennialConvention(28 Ekim- 01 Kasım 2017) Kongresinde sözel bildiri olarak sunulmuştur. 


\title{
Caregiver outcomes of geriatric oncology patients
}

\begin{abstract}
Objective: Care and treatment of elderly is very special due to the excess number of diseases accompanying the old age, intensity of the symptoms, decrease in age-related functional adequacy, limitations experienced in personal care and special procedures followed during the treatment. This study was conducted to determine the outcomes and changes occurred due to caregiving for elderly patients with cancer. Method: The sample size of the descriptive study was composed of 70 caregivers of the patients with cancer diagnosis. Sample size was calculated with power analysis (\%80 power, $5 \%$ level of significance, 0.50 effect size). Data was collected with socio-demographic form (23 questions) and Bakas Caregiving Outcomes Scale (score 15-105, higher scores shows positive impact). Ethical committee approval of the study and written consent from caregivers were obtained. Data was analyzed with descriptive statistics, $\mathrm{t}$ test, Kruskal Wallis and Mann Whitney U tests. Results: Patient mean age was 73.1 \pm 7.2 (Min=63- Max=92) and 55.7\% of them were women. Gastrointestinal system cancer, leukamia were the most common diagnosis with $3.3 \pm 4.6$ months (Min=1- Max=36 month) diagnosis period. Caregivers mean age was 51.3 \pm 11.9 (Min=24- Max.78), 77.1\% women, $87.1 \%$ married, $50 \%$ were living with patients, $61.4 \%$ were children of patients $(24.3 \%$ daughter, $17.1 \%$ son). The mean score of Bakas Caregiving Outcomes Scale was 51.7 \pm 8.9 . Caregivers reported negative impact in "physical health, coping strategies, relationship with friends, energy level, emotional wellness, time for social activities and physical functioning" and positive impact in "relationship with the patient". Conclusion: It has emerged that caregiving has a negative effect on the physical and psychological health of the caregivers but opposite influence on the continuing relationship with the patient. The study also showed that the cancer type, gender, age (late aged period), level of education, and age of the caregiver, working status and relationship with the patient increased the burden on the care delivery process.
\end{abstract}

Key Words: Caregiving, geriatric oncology, impact of caregiving

\section{Giriş}

Dünyada ve ülkemizde toplam nüfus içerisindeki yaşlı nüfusun artışı kronik hastalık ve kanser gibi ciddi sağlık sorunlarında artışa yol açmaktadır. Ülkemiz verileri değerlendirildiğinde toplam kanser insidansının \%60'ından fazlasının ve tüm kanser ölümlerinin \%67'sinin 65 yaş ve üzeri kişilerde oluştuğu bildirilmektedir.1-3

Kanser tanısı ile izlenen yaşlı bireyin tedavi ve bakımı; yaşlılık dönemine eşlik eden hastalık sayısındaki fazlalık, var olan hastalıklara bağlı semptomların yoğunluğu, yaşla birlikte azalan fonksiyonel yeterlilik, öz bakım yeteneği ve gücündeki sınırlılıklar nedeniyle profesyoneller tarafından sunulan sağlık hizmeti ile birlikte aile tarafından sağlanan bakım faaliyetlerinigerektirmektedir. ${ }^{3-5} \mathrm{Aile}$

tarafından yaşlı bireylere, tanı, tedavi, semptom yönetimi gibi süreçlerin tümünde sağlanan veinformal bakım olarak adlandırılan bu sorumluluk bakım veren aile ve yakınlarını duygusal, sosyal ve ekonomik sınırlılıklar ile karşı karşıya birakmakta ve destek gereksinimi oluşturmaktadır.6,7Ancak, ülkemizde sınırlı sunulan evde bakım hizmetleri ya da değişen sağlık politikaları nedeniyle bakım veren aile ve yakınları ihtiyaç duydukları desteğe her zaman ulaşamamakta ve daha fazla sorumluluk almak durumunda kalmaktadır. ${ }^{5}$ Konu alanı ile ilgili yurtdışında ve ülkemizde yapılan çalışmalar; bakım verenlerin yaşlı bireyin semptomları ile baş etmede yetersizlik, bakım sürecinde beklenmeyen ihtiyaçların ortaya çıkması nedeniyle stres ve tükenmişlik yaşadıkları ve bu sürecin bakım verenlerinyaşamındadeğişiklik

yaşanmasına neden olduğunu göstermektedir.4,5,7,8

Ülkemizde yaşlı bireyler ile bakım veren bireylere yönelik çalışma sonuçları bulunsa da; 65 yaş ve üzerinde kanser tanısı almış hastalara ve onların bakım 
verenlerine yönelik araştırmaların sınırlı olduğu görülmektedir. $\mathrm{Bu}$ nedenle çalışmada, 65 yaş ve üzeri kanser hastalarına bakım verenlerin yașadı̆̆ güçlüklerin ve yaşamlarında oluşan değişimlerin belirlenmesi amaçlanmaktadır. Çalışmanın sonuçlarının; yaşlı kanser hastasına bakım verenlerin güçlük yaşadığı bakım alanlarının belirlenmesine ve bakım verenleri güçlendirmeye yönelik çalışmaların geliştirilmesine katkıda bulunacağı düşünülmektedir.

\section{Gereç ve Yöntemler}

Araştırmanın tipi:Araştırma, 65 yaş ve üzerinde kanser tanısı ile izlenen hastalara bakım veren bireylerin yaşamında, bakım verme nedeniyle oluşan değișikliklerin belirlenmesi amacıyla tanımlayıcı olarak gerçekleştirilmiştir.

Araştırmanın evren ve örneklemi:Çalışma Ankara ilinde bakanlığa bağlı hizmet veren onkoloji hastanesi yataklı kliniklerinde Haziran-Aralık 2016 tarihleri arasında yapılmıştır. Araştırma evrenini belirtilen tarihlerde hastanenin kliniklerinde yatan 65 yaş ve üzeri kanser tanısı almış hastalara bakım veren bireyler oluşturmuştur. Evrenden dahil edilme kriterlerini karşılayan ve araştırmaya katılmaya gönüllü bireyler alınmıştır. Örnekleme dahil edilme kriterleri, bakım verenlerin 18 yaş ve üzerinde ve okur-yazar olmasıdır.

Örnekleme alınacak bakım veren sayısının hesaplanmasında güç analizi kullanılmıştır. Güç analizi, araştırma kapsamına alınan ilk 10 kişinin verileri kullanılarak yapılmıştır. Pilot çalışmada Bakas Bakım Verme Etki Ölçek puan ortalaması 55.6, standart sapma 8.2, ortancası 56.0, minimum ölçek puanı 38.0, maksimum puan ise 64.0 olarak elde edilmiştir. Pilot çalışma verileri ve alfa değeri 0.05 , beta değeri 0.20 , etki büyüklüğü 0.50 (orta büyüklük) olarak yapılan hesaplamada örnekleme alınacak kişi sayısı 70 olarak belirlenmiştir.

Veri toplama araçları: Araştırmanın verileri Tanıtıcı Bilgiler Formu ve Bakas Bakım Verme Etki Ölçeği ile toplanmıştır.
"Tanitıcı Bilgiler Formu", hastaların ve bakım verenlerin sosyo-demografik özelliklerini belirlemek amacıyla hazırlanan 23 (10 soru hasta bireyi tanımlayıcl, 13 soru bakım veren bireyleri tanımlayıcı)sorudan oluşmaktadır. Form ilgili literatürün taranması ile oluşturulmuştur. ${ }^{3-6}$

"Bakas Bakım Verme Etki Ölçeği" bakım verenlerin yaşantılarını bakım verme sürecinin başlaması ile nasıl değiştiğini değerlendirmek amacıyla 1994 yılında Bakas tarafından geliştirilmiştir. Ölçek 16 maddeden oluşmakta, 16 madde bakım vermenin olumlu ve olumsuz yaşantı değişikliklerini en iyi yönde $(+3)$ ve en kötü yönde (-3) olmak üzere değerlendirmektedir (min. 15, max. 105). Alt boyutları bulunmayan ölçekten alınan toplam puan arttıkça "iyi yönde değişim", azaldıkça "kötü yönde değişim" yorumu yapılmaktadır. Ölçeğin Türkçe geçerlilikgüvenirlik çalıșması Can ve Cavlak $^{9}$ tarafından 2010 yılında yapılmış ve çalışmada ölçeğin iç tutarlılık sayısı 0.90 , test-tekrar test güvenirliği ise 0.961 olarak bulunmuștur.

Araştırmanın uygulanması: Araştırma kapsamına alınacak bakım verenlerin belirlenmesi için öncelikle kliniklerde yatan 65 yaş ve üzeri onkoloji hastaları tanımlanmıştır. Daha sonra bu hastaların bakım verici aile bireylerine araştırmanın amacı açıklanmış, detaylı bilgi için araştırma gönüllü olur formunu okumaları istenmiştir. Araştırmaya katılmaya gönüllü olduğunu bildiren hasta yakınları uygun bulmaları halinde o anda ya da kendileri için uygun olan bir zamanda soru formlarını yanıtlamaları istenmiştir. Veriler klinikte (hasta odası-dinlenme odasında yüz yüze görüșme yöntemi ile) toplanmıștır. Veri toplama süresi bir birey için yaklaşık 10 dakika sürmüştür.

Verilerin değerlendirilmesi ve araştırmanın etik boyutu: Veriler IBM SPSS Statistics v23 programinda analiz edilmiştir. Araştırma verilerinin analizinde tanımlayıcı istatistiksel testler ile ölçek puanlarının normal dağılım göstermemesi nedeniyle (Shapiro-Wilk 0.947, p:0.005; Kolmogorov-Smirnov 0.114, p:0.24) non- 
parametrik testlerden Kruskal Wallis ile Mann Whitney U testleri kullanılmıștır. ${ }^{10}$

Araştırma için kurumlardan yazılı izin ve etik kurul izni (G016/107-05) alınmıştır. Çalışmaya katılan bakım verenler araştırmaya gönüllü katılım formunu onaylamıştır.

\section{Bulgular}

Hastaların tanıtıcı özellikleri: Araştırmaya katılan hastaların yaş ortalaması 73.1 \pm 7.2(En düşük=63- En yüksek=92), \%55.7'si kadın, \%88.6'sı ilkokul mezunu, \%62.9'u evli, \%97.1'i çocuk sahibi ve tamamı çalışmıyor durumdadır. Hastaların $\% 40.0$ 'ı kendi evinde eşiyle, \%22.8'i ise çocuklarının yanında eşiyle birlikte yaşamaktadır.

Hastaların onkolojik tanıları; gastrointestinal sistem kanserleri, lösemi, genitoüriner sistem kanserleri velenfoma olarak sıralanmıştır. Hastaların tanı süresi ortalama 3.3 \pm 4.6 aydır (En düşük=1 - En yüksek=36 ay), \%65.7'sinde kanser tanısına eşlik eden en az bir kronik hastalık bulunmaktadır. Eşlik eden hastalıklar ise sıklıklarına göre hipertansiyon (\%48.8), diyabet (\%26.1), kalp yetmezliği (\%10.7), KOAH (\%6), Alzheimer (\%4.8) ve tiroid hastalıkları (\%3.6) olarak belirtilmiştir (Tablo 1).

Bakım verenlerin tanıtıcı özellikleri: Bakım verenlerin yaş ortalaması $51.3 \pm 11.9$ (En düşük=24 - En yüksek=78), \%77.1'i kadın, \%47.1'i ilkokul mezunu, \%87.1'i evli, \%88.5'i çocuk sahibi, \%72.9'u çalışmıyor durumdadır. Bakım verenlerin \%42.9'u eş ve çocukları ile yaşamakta, \%60.0'ı gelirinin giderine denk olduğunu ifade etmektedir. Bakım verenlerin \%44.3'ü hastanın kızı, \%24.3'ü eşi, \%17.1'i oğludur ve \%50'si hasta ile birlikte yaşamaktadır. Ortalama $12.6 \pm 26.0$ aydır (En düşük=1 - En yüksek=144) bakım veren bireylerin \%12.9'unun bakım verdiği başka bir birey olduğu ve \%92.9'unun bakım sürecinde destek almadığı saptanmıştır (Tablo 1).

Bakım Veren Etki ölçeğine İlişsin Bulgular: Bakım verenlerin Bakas ölçek puan ortalaması $51.7 \pm 8.9$, ortancası 53.5 , en düşük puan 27, en yüksek puan 65 'tir.

Kadın ( $\mathrm{X}_{\text {ort }} 52.0$ ), 43-61 ( $\mathrm{X}_{\text {ort }} 51.0$ ) ve 62-78 ( $\left.\mathrm{X}_{\text {ort }} 52.0\right)$ yaş aralığında, eğitim düzeyi düşük $\left(\mathrm{X}_{\text {ort }} 52.0\right)$, bekar ( $\left.\mathrm{X}_{\text {ort }} 51.0\right)$,

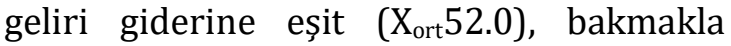
yükümlü olduğu başka kişi olmayan $\left(X_{\text {ort } 53.0)}\right.$ ve hastası ile birlikte yaşayan $\left(\mathrm{X}_{\text {ort }} 52.0\right)$ bakım verenlerin ölçek puan ortancalarının diğer gruplardan daha düşük olduğu ve farkın istatistiksel olarak anlamlı olmadığı $\quad(p>0.05)$ bulunmuştur. Diğer taraftan çalışmayan ( $\left.\mathrm{X}_{\text {ort }} 51.0\right)$, ve hastanın kızı olan ( $\left.\mathrm{X}_{\text {ort }} 49.0\right)$ bakım verenlerin ölçek puan ortancalarının düşük olduğu ve aradaki farkın istatistiksel olarak anlamlı olduğu bulunmuştur ( $\mathrm{p}<0.05)$, (Tablo 2).

Kadın $\quad\left(X_{\text {ort }} 51.0\right), \quad 75-84$ yaș aralığında $\left(\mathrm{X}_{\text {ort }} 51.0\right)$ ve ilkokul mezunu ( $\mathrm{X}_{\text {ort } 52.5)}$ hastaya bakım verenlerin ölçek puan ortancalarınındiğer gruplardan düşük olduğu ve farkın istatistiksel olarak anlamlı olmadığı saptanmıştır $\quad(p>0.05)$. MultipleMiyelom, beyin tümörü, yüzde kitle, dudak kanseri, tiroid kanseri gibi diğer grubunda yer alan kanser $\left(\mathrm{X}_{\text {ort }} 46.5\right)$ ve lösemi $\left(\mathrm{X}_{\text {ort }} 50.0\right)$ tanısı ile izlenen hastalara bakım veren bireylerin ölçek puan ortancalarının düşük olduğu ve aradaki farkın istatistiksel olarak anlamlı olduğu bulunmuştur ( $\mathrm{p}<0.05)$, (Tablo 2).

Bakım verenler Bakas Bakım Veren Etki Ölçeği "fiziksel sağlık, stresle başa çlkabilme yeteneği, arkadaşlarla olan ilişki, enerji düzeyi, duygusal iyilik hali, arkadaşlarla sosyal aktiviteler için zaman ve fiziksel işlevselliğim" maddelerinde olumsuz yönde değişim bildirmişlerdir. "Kendine güven/öz saygı, aile aktiviteleri için zaman, aileyle ilişki, geleceğe bakıș açısı, yaşamdaki roller, maddi iyilik durumu, genel sağlık" maddelerinde değişim ifade etmemişlerdir. Bakım verenler ölçek maddelerinden yalnızca "bakıma ihtiyacı olan hastamla ilişkim" maddesinde olumlu yönde değişim bildirmişlerdir. Bakım verenler genel olarak hasta bakımını üstlenmenin yaşam üzerindeki değişimini olumsuz (\%42.9) ve değişmedi (\%48.6) olarak değerlendirmişlerdir (Tablo 3). 
Tablo 1. Bakım veren ve hastaların tanıtıcı özellikleri (n:70)

\begin{tabular}{|c|c|c|c|c|c|}
\hline \multicolumn{3}{|l|}{$\begin{array}{l}\text { Hastaya Ait Özellikler } \\
\text { Yaş 73.06 } \pm 7.19(\min .63-\max .92)\end{array}$} & \multicolumn{3}{|c|}{$\begin{array}{l}\text { Bakım Verene Ait Ozellikler } \\
\text { Yaș 51.33 } \pm 11.96(\min .24-m a x .78)\end{array}$} \\
\hline $65-74$ & 49 & 70.0 & $24-42$ & 18 & 25.7 \\
\hline $75-84$ & 16 & 21.4 & $43-61$ & 39 & 55.7 \\
\hline $85-92$ & 6 & 8.6 & $62-78$ & 13 & 18.6 \\
\hline \multicolumn{3}{|l|}{ Cinsiyet } & \multicolumn{3}{|l|}{ Cinsiyet } \\
\hline Kadın & 39 & 55.7 & Kadın & 54 & 77.1 \\
\hline Erkek & 31 & 44.3 & Erkek & 16 & 22.9 \\
\hline \multicolumn{3}{|l|}{ Eğitim Durumu } & \multicolumn{3}{|l|}{ Eğitim Durumu } \\
\hline Illkokul & 62 & 88.6 & İlkokul & 33 & 47.1 \\
\hline Ortaokul & 2 & 2.9 & Ortaokul & 14 & 20.0 \\
\hline Lise & 2 & 2.9 & Lise & 13 & 18.6 \\
\hline Önlisans & 3 & 4.3 & Önlisans & 6 & 8.6 \\
\hline Lisans & 1 & 1.4 & Lisans & 4 & 5.7 \\
\hline \multicolumn{3}{|l|}{ Medeni Durum } & \multicolumn{3}{|l|}{ Medeni Durum } \\
\hline Evli & 44 & 62.9 & Evli & 61 & 87.1 \\
\hline Bekâr & 26 & 37.1 & Bekâr & 9 & 12.9 \\
\hline \multicolumn{3}{|l|}{ Çocuk Sahibi Olma Durumu } & \multicolumn{3}{|c|}{ Çocuk Sahibi Olma Durumu } \\
\hline Yok & 2 & 2.9 & Yok & 8 & 11.5 \\
\hline Var & 68 & 97.1 & Var & 62 & 88.5 \\
\hline \multicolumn{3}{|l|}{ Çalışma Durumu } & \multicolumn{3}{|l|}{ Çalıșma Durumu } \\
\hline Çalıșmıyor & 70 & 100.0 & Çalıșmiyor & 51 & 72.9 \\
\hline Çalışıor & - & - & Çalışıyor & 19 & 27.1 \\
\hline \multicolumn{3}{|l|}{ Birlikte Yaşadığı Kişiler } & \multicolumn{3}{|c|}{ Birlikte Yaşadığı Kişiler } \\
\hline Eşi ile & 28 & 40.0 & Eşi ile & 21 & 30.0 \\
\hline Çocukların yanında eşi ile & 16 & 22.8 & Eş ve çocuklar & 30 & 42.9 \\
\hline Eş ve çocuklar & 14 & 20.0 & Anne, baba, aile & 15 & 21.4 \\
\hline Yalnız & 12 & 17.2 & Yalnız veya kızıyla & 4 & 5.7 \\
\hline \multicolumn{3}{|l|}{ Tani* } & \multicolumn{3}{|c|}{ Hasta ile Yakınlık Derecesi } \\
\hline Gastrointestinal sistem kanserleri & 13 & 18.6 & Çocuğu*** & 43 & 61.4 \\
\hline Lösemi & 12 & 17.1 & Eşi & 17 & 24.3 \\
\hline Genitoüriner sistem kanserleri & 10 & 14.3 & Kardeși & 4 & 5.7 \\
\hline Lenfoma & 7 & 10.0 & Gelini & 3 & 4.3 \\
\hline Solunum sistemi kanserleri & 7 & 10.0 & Akraba & 3 & 4.3 \\
\hline Jinekolojik kanserler & 5 & 7.2 & \multicolumn{3}{|c|}{ Bakım Veren ile Birlikte Yaşama Durumu } \\
\hline Meme Kanseri & 4 & 5.7 & Evet & 35 & 50.0 \\
\hline Diğer & 12 & 17.1 & Hayır & 35 & 50.0 \\
\hline \multicolumn{3}{|l|}{ Tanı Süresi } & \multicolumn{3}{|c|}{ Bakım Verme Süresi } \\
\hline \multicolumn{3}{|l|}{$3.3 \pm 4.6$ ay (min.1-max.36) } & \multicolumn{3}{|c|}{$12.6 \pm 26.0$ ay (min.1-max.144) } \\
\hline \multicolumn{3}{|l|}{ Eşlik Eden Hastalıklar (n:84)** } & \multicolumn{3}{|c|}{ Bakmakla Yükümlü Olduğu Bașka Biri } \\
\hline Hipertansiyon & 41 & 48.8 & Var & 9 & 12.9 \\
\hline Diyabet & 22 & 26.1 & Yok & 61 & 87.1 \\
\hline Kalp Yetmezliği & 9 & 10.7 & Bakım Sürecinde & Irun & \\
\hline Diğer (КОАН, Alzheimer, Tiroid & 12 & 14.4 & Alıyor & 5 & 7.1 \\
\hline bozuklukları,) & & & Almiyor & 65 & 92.9 \\
\hline $\begin{array}{l}\text { * Gastrointestinal sistem kanserleri } \\
\text { Genitoüriner sistem kanserleri (mes } \\
\text { larinks 1, nazofarenks 1), Jinekolojik } \\
\text { dudak 2, beyin tümörü 2, tiroid 3, MM }\end{array}$ & $\begin{array}{l}\text { kar } \\
4)\end{array}$ & $s_{0}$ & viste kitle 3, mide & & $\begin{array}{l}\text { i } 2) \\
\text { er } 5 \\
\text { le } 1\end{array}$ \\
\hline ** Birden çok cevap verilmiştir & & & & & \\
\hline *** Kızı 31, oğlu 12 & & & & & \\
\hline
\end{tabular}


Tablo 2. Bakım verenlerin özelliklerine göre BAKAS puanları

\begin{tabular}{|c|c|c|c|c|c|c|c|c|c|c|c|}
\hline $\begin{array}{l}\text { Bakım Verene Ait } \\
\text { Özellikler } \\
\text { Yaş }\end{array}$ & $\mathrm{n}$ & $\%$ & $\begin{array}{l}\text { Ortanca } \\
\text { (min-max) }\end{array}$ & $\begin{array}{l}\text { MeanR } \\
\text { ank }\end{array}$ & Analiz & $\begin{array}{l}\text { Hastaya Ait } \\
\text { Özellikler } \\
\text { Yaş }\end{array}$ & $\mathrm{n}$ & $\%$ & $\begin{array}{l}\text { Ortanca } \\
\text { (min-max) }\end{array}$ & $\begin{array}{l}\text { Mean } \\
\text { Rank }\end{array}$ & Analiz \\
\hline $24-42$ & 18 & 25.7 & $55.5(43-63)$ & 39.7 & $X^{2}: 1.029$ & $65-74$ & 49 & 70.0 & $54.0(36-65)$ & 35.4 & $X^{2}: .922$ \\
\hline $43-61$ & 39 & 55.7 & $51.0(27-65)$ & 33.9 & p:.598 & $75-84$ & 15 & 21.4 & $51.0(27-64)$ & 33.0 & p:.631 \\
\hline $62-78$ & 13 & 18.6 & $52.0(41-61)$ & 34.6 & & $85-92$ & 6 & 8.6 & $58.0(43-62)$ & 42.4 & \\
\hline Cinsiyet & & & & & & Cinsiyet & & & & & \\
\hline Kadın & 54 & 77.1 & $52.0(27-65)$ & 32.9 & Z: -1.939 & Kadın & 39 & 55.7 & $51.0(27-65)$ & 31.5 & Z: -1.852 \\
\hline Erkek & 16 & 22.9 & $57.5(28-64)$ & 44.2 & p: .052 & Erkek & 31 & 44.3 & $56.0(28-64)$ & 40.5 & p: .064 \\
\hline Eğitim Durumu & & & & & & Eğitim Durumu & & & & & \\
\hline İlköğretim & 47 & 67.1 & $52.0(28-64)$ & 33.8 & Z: - .983 & İlkokul & 62 & 88.6 & $52.5(27-65)$ & 34.5 & Z: -1.099 \\
\hline $\begin{array}{l}\text { Ortaöğretim ve üzeri } \\
\text { Medeni Durum }\end{array}$ & 23 & 32.9 & $55.0(27-65)$ & 38.9 & p: .326 & $\begin{array}{l}\text { İlkokul üzeri } \\
\text { Hastanın Tanısı }\end{array}$ & 8 & 11.4 & $55.5(48-64)$ & 42.9 & p: .272 \\
\hline Evli & 61 & 87.1 & $54.0(27-65)$ & 35.8 & Z: -.369 & Gastrointestinal & 13 & 18.6 & $52.0(44-63)$ & 34.7 & $X^{2}: 13.142$ \\
\hline Bekar & 9 & 12.9 & $51.0(33-63)$ & 33.2 & p: .712 & sistem kanserleri & & & & & p:.041 \\
\hline Çalıșma Durumu & & & & & & Lösemi & 12 & 17.1 & $50.0(28-64)$ & 31.0 & \\
\hline Çalışmıyor & 51 & 72.9 & $51.0(27-64)$ & 31.3 & Z: -2.816 & Genitoüriner & 10 & 14.3 & $59.5(52-64)$ & 55.0 & \\
\hline Çalışıyor & 19 & 27.1 & $58.0(36-65)$ & 46.7 & p: .005 & sistem kanserleri & & & & & \\
\hline Gelir Durumu & & & & & & Lenfoma & 7 & 10.0 & $54.0(45-65)$ & 39.4 & \\
\hline Geliri giderinden az & 27 & 38.6 & $54.0(28-64)$ & 36.0 & Z: -.151 & Solunum sistem & 7 & 10.0 & $52.0(36-63)$ & 34.4 & \\
\hline Geliri giderine eșit & 43 & 61.4 & $52.0(27-65)$ & 35.2 & p: .880 & kanserleri & & & & & \\
\hline Hasta ile Yakınlık De & ecesi & & & & & Jinekoloji kanserler & 9 & 12.9 & $54.0(27-63)$ & 31.8 & \\
\hline Kızı & 31 & 44.3 & $49.0(27-65)$ & 28.8 & $X^{2}: 8.150$ & Diğer & 12 & 17.1 & $46.5(33-62)$ & 25.7 & \\
\hline Oğlu & 12 & 17.1 & $58.5(28-64)$ & 47.6 & p:.04 & \multicolumn{6}{|c|}{ Bakım Veren ile Hastanın Birlikte Yaşama Durumu } \\
\hline Eşi & 17 & 24.3 & $54.0(41-61)$ & 36.7 & & Evet & 35 & 50.0 & $52.0(27-63)$ & 34.5 & $Z:-.406$ \\
\hline Yakınları & 10 & 14.3 & $55.0(40-64)$ & 39.7 & & Hayır & 35 & 50.0 & $54.0(28-65)$ & 36.5 & p: .685 \\
\hline \multicolumn{12}{|c|}{ Bakmakla Yükümlü Olduğu Başka Biri } \\
\hline Var & 9 & 12.9 & $57.0(43-59)$ & 34.9 & Z: -.615 & & & & & & \\
\hline Yok & 61 & 87.1 & $53.0(27-65)$ & 39.4 & p: .539 & & & & & & \\
\hline
\end{tabular}


Tablo 3. BAKAS ölçek maddelerine ilişkin dağılım

\begin{tabular}{|c|c|c|c|c|c|c|}
\hline \multirow[b]{3}{*}{ Kendime güvenim / öz saygım } & \multicolumn{2}{|c|}{$\begin{array}{c}\text { En Kötü Yönde } \\
\text { Değiști } \\
(-3,-2,-1)\end{array}$} & \multicolumn{2}{|c|}{$\begin{array}{l}\text { Değişmedi } \\
\quad(0)\end{array}$} & \multicolumn{2}{|c|}{$\begin{array}{c}\text { En İyi Yönde } \\
\text { Değişti } \\
(+3,+2,+1)\end{array}$} \\
\hline & $\mathrm{n}$ & $\%$ & $\mathrm{n}$ & $\%$ & $\mathrm{n}$ & $\%$ \\
\hline & 9 & 12.8 & 56 & 80.0 & 5 & 7.2 \\
\hline Fiziksel sağlı̆ı̆m & 46 & 65.7 & 24 & 34.3 & - & - \\
\hline Aile aktiviteleri için zamanım & 34 & 48.6 & 35 & 50.0 & 1 & 1.4 \\
\hline $\begin{array}{lll}\text { Stresle } & \text { başa } & \text { çlkabilme } \\
\text { yeteneğim } & & \end{array}$ & 42 & 60.0 & 20 & 28.6 & 8 & 11.4 \\
\hline Arkadaşlarla olan ilişkim & 42 & 54.9 & 26 & 37.1 & 2 & 2.8 \\
\hline Geleceğe bakış açım & 18 & 25.8 & 46 & 65.7 & 6 & 8.6 \\
\hline Enerji düzeyim & 52 & 74.3 & 13 & 18.6 & 5 & 7.1 \\
\hline Duygusal iyilik halim & 38 & 54.2 & 17 & 24.3 & 15 & 21.4 \\
\hline Yaşamdaki rollerim & 22 & 31.4 & 42 & 60.0 & 6 & 8.6 \\
\hline $\begin{array}{l}\text { Arkadaşlarımla sosyal aktiviteler } \\
\text { için zamanım }\end{array}$ & 45 & 64.2 & 25 & 35.7 & - & - \\
\hline Ailemle ilişkim & 15 & 21.4 & 51 & 72.9 & 4 & 5.7 \\
\hline Maddi iyilik durumum & 24 & 34.3 & 46 & 65.7 & 0 & \\
\hline $\begin{array}{l}\text { Bakıma ihtiyacı olan hastamla } \\
\text { ilișkim }\end{array}$ & 10 & 14.3 & 17 & 24.3 & 43 & 61.5 \\
\hline Fiziksel işlevselliğim & 37 & 52.9 & 31 & 44.3 & 2 & 2.9 \\
\hline Genel sağlığım & 23 & 32.9 & 45 & 64.3 & 2 & 2.9 \\
\hline $\begin{array}{l}\text { Genel olarak; bakıma ihtiyacı } \\
\text { olan hastanın bakımını } \\
\text { üstlenmenin bir sonucu olarak } \\
\text { yașamınız nasıl değiști? }\end{array}$ & 30 & 42.9 & 34 & 48.6 & 6 & 8.6 \\
\hline
\end{tabular}

\section{Tartışma}

Bakım verenlerin Bakas "Bakım Veren Etki Ölçeği”nden aldıkları toplam puan orta düzeyde bulunmuștur. Bu sonuç bakım verenlerin, bakım verme süreci nedeniyle yaşamlarında belirgin düzeyde iyi ya da kötü yönde bir değişim deneyimlemediklerini göstermektedir. Diğer taraftan ölçek ortalamalarından farklı olarak bakım verenler, ölçeğin "fiziksel sağlık, stresle başa çlkabilme yeteneği, arkadaşlarla olan ilişki, enerji düzeyi, duygusal iyilik hali, arkadaşlarla sosyal aktiviteler için zaman ve fiziksel işlevselliğim" maddelerinde olumsuz yönde değişim bildirmişlerdir. Konu ile ilgili yapılan çalışmalar da bakım vermenin, bakım veren bireylerin yaşamlarında değişime (genellikle olumsuz yönde) neden olduğunu ortaya koymaktadır. $\mathrm{Bu}$ değişimler uyku-dinlenme bozuklukları, anksiyete ${ }^{6,11}$, depresyon ${ }^{12,13}$, yaşam kalitesinde azalma, fonksiyonel performansta azalma, duygusallıkta artma, işgücü kaybı14, artan bakım yükünün yarattığı stres ${ }^{15}$, dikkatte azalma, isteksizlik, güçsüzlük, ümitsizlik, aile içi ilişkilerde değişim, finansal sorunlar ${ }^{11}$ olarak sıralanmaktadır. Çalışmamızda ölçeğin belli maddelerinde olumsuz yönde bir değişim tanımlanmasına rağmen ölçek toplam puanına göre iyi ya da kötü yönde belirgin olarak tanımlanmamıș olan değișimin bakım verenlerin büyük bir çoğunluğunun bakım vermeyi geleneksel olarak kabul edilmiş ve benimsenmiş rol olarak görmesinden kaynaklandığı söylenebilir.

Bakım verene ait yaş, etnik köken, cinsiyet, akrabalık düzeyi, isteyerek bakım verme sorumluluğunu alma, eğitim durumu, ekonomik durum, hastalığının olup olmaması, baş etme becerileri, inançları, yardım alabileceği kaynakların varlığı, içinde yaşadığı toplumun bakım süreci ile ilgili yaklaşımları bakım verenin yük algılaması ile ilişkili faktörler olarak 
belirtilmiştir. ${ }^{14-17}$ Ancak bu çalışmada, Maguire ve arkadaşları ${ }^{18}$ tarafından ortaya konan sonuçlara benzer olarak, bakım verenlere ait yaş, cinsiyet, eğitim durumu, medeni durum, gelir düzeyi, bakım verdiği bireyle birlikte yaşama durumu ve bakmakla yükümlü olduğu başka birinin varlığl, değişkenlerinin bakım verme sürecinden etkilenme durumunda değişikliğe neden olmadığı bulunmuştur. Elde edilen bu bulgunun bireylerin bir parçası oldukları toplumun bakım verme sorumluluğuna ya da bazen zorunluluğuna ilişkin kültürel yaklaşımından ya da belirtilen tüm değişkenlerden bağımsız olarak yaşamlarının bir döneminde böyle bir rol (yaşlanan yakına bakma) ile karşı karşıya kalmaya hazırlıklı olmalarından kaynaklandığı düşünülebilir.

Diğer taraftan, bakım verenin çalışma durumu ve hasta ile yakınlık derecesinin bakım verme sürecinde etkilenmeye neden olduğu saptanmıştır. Sosyo-ekonomik yapıdaki değişmeler aile sürecinde kadın ya da erkek herkesin aile bütçesine katkı yapmasını zorunlu kılmıștır. $\mathrm{Bu}$ nedenle bakım verenler bir taraftan çalıșmakta diğer taraftan ise yaşlı ya da ihtiyacı olan bireye bakım verme süreci ile ilgili hem düzenlemelerin sorumluluğunu almakta ya da yeri geldiğinde gereksinim duyulan bakımı kendisi gerçekleştirmek durumunda kalmaktadır. Bu durum bakım verenin yükünü ve dolayısıyla karşı karşıya kaldığı semptomları etkilemektedir.19,20 Diğer yandan bireyin bakım verene yakınlık derecesi artıkça ${ }^{22}$ geleneksel olarak kendisine yüklenen ve dolayısı ile hissedilen yük artmaktadır.

Bakım verilen hastanın yaşı, cinsiyeti, eğitim durumu bakım verenin etkilenme durumunu değiştirmezken, hastanın kanser türünün bakım verenin etkilenme durumunu değiştirdiği bulunmuștur. Bakım verilen birey ailenin bir parçası olduğunda bakılan bireye ait kișisel özellikler bakım verme yükünü etkilememektedir. Ancak kanser tanısı, özellikle ileri evre ve yoğun tedavi süreci söz konusu olduğunda, baş etmesi güç bir süreci barındırmaktadır. ${ }^{20}$ Tanıya eşlik eden ve yaşlanmayla gelen değişimler de, bakım verme sürecinde ihtiyaç duyulan fiziksel, psikolojik ya da duygusal desteği değiştirdiği için bakım vericiye ek yükler getirebilmektedir. $\mathrm{Bu}$ dönemde bakım verenin karșılaștığı yükün, hem fiziksel hem de kanserli ve yaşlı hastayla vedalaşma, hayatının son dönemindeki aile üyesine karşı son görevin yerine getirme gibi duygusal durumlardan kaynaklandığ düşünülebilir (16).

Kadın, 43-61 ve 62-78 yaş aralığında, eğitim düzeyi düşük, bekâr, geliri giderine eşit, bakmakla yükümlü olduğu başka bir kişi olmayan ve hastası ile birlikte yaşayan bakım verenlerin yaşamlarında ortaya çıkan etkilenmenin kötü yönde olduğu bulunmuştur. Literatürde genç yaşta $^{21}$ ve ileri yaşta bakım verme sorumluluğu üstlenen bireylerin bakım verme yükünün daha fazla olduğunu gösteren çalışma sonuçları yer almaktadır.6,19 Genç yaşlar, geç gelmesi beklenilen bakım verme sorumluluğunu kabul etmenin ve hastalık yükü ile mücadele etmenin güç olduğu dönemlerdir ancak bu çalışmada belirlendiği gibi yaş ilerledikçe hissedilen değișimdeki artıș bakım veren bireyin bir taraftan bakım verdiği hastanın diğer taraftan kendi yașamının getirdiği sorumlulukları sürdürmeye çalışması ile ortaya çıkan güçlükten kaynaklandığı düşünülmektedir.

Benzer şekilde bakım verdiği hastanın kadın, 75-84 yaş aralığında ve eğitim düzeyinin düşük olması durumunda da bakım verenlerin yaşamlarında ortaya çıkan değişimin kötü yönde olduğu saptanmıştır. Yaşın ilerlemesi normalde tolere edebilir pek çok değişimin zor kabul edildiği ayrıca yaşamı kaybetme ile yüzleşmenin yaşandığı bir dönemdir. Bu dönemde hasta birey hastalık semptomların yanı sıra dönemsel değişimlerle de mücadele etmek durumunda kalmaktadır. Yaş kadar, hastanın hastalık durumu ile ortaya çıkan değişimi nasıl algılandığı da önem kazanmaktadır. ${ }^{18} \mathrm{Bu}$ nedenle bakım veren bireylerden beklentileri ve yaşamına dair sorumlulukları paylaşma isteği artmakta bu da bakım verenin hissettiği yükü artırmaktadır. Hasta bireyin eğitim düzeyi düştükçe bakım verenin kendini anlatma, hasta ile etkin iletişimi sürdürme ve anlaşıldığını hissetme oranının 
düşmesinin de süreçte yaşanan etkilenmenin kötü olarak algllanmasına neden olduğu söylenebilir.

Çalışmada ayrıca; multiplemiyelom, beyin tümörü, yüzde kitle, dudak kanseri, tiroid kanseri ve lösemi tanısı ile izlenen hastaya bakım veren ve çalışmayan bakım verenlerin yaşamlarında ortaya çıkan etkilenmenin kötü yönde olduğu bulunmuştur. Elde edilen bu bulgunun kanser hastalığının kendisinin bireyin yaşamına kattığı fiziksel, duygusal ve psikolojik sorunlardan kaynaklandığ düșünülmektedir. Kanser tanısı almış bireye bakım verenler bu nedenle bir taraftan hastalığın kendisinin yarattığı sorunlar ile mücadele ederken, diğer taraftan hastalığın sonuçlarını hasta ile birlikte yaşamakta ve bu süreçle ilgili sorunlarla mücadele etmek zorunda kalmaktadır.

Hastanın kızı olan bakım verenlerin yaşamlarında ortaya çıkan değişimin kötü yönde olduğu, hastanın oğlu olan bakım verenlerin yaşamlarında ortaya çıkan etkilenmenin ise iyi yönde olduğu bulunmuştur. Konu alanı çalışmaları incelendiğinde; bakım verenlerin ağırlıklı olarak kadınlardan oluştuğu görülmektedir.6,14,15 Çalışmadan elde edilen bu bulgunun kadının geleneksel olarak ev içinde yüklendiği ve doğal bir sorumluluk olarak algıladığı ve kabul ettiği, bakım sorumluluğu ile uyumlu olmasindan kaynaklandığı düşünülebilir. Ayrıca içinde bulunduğumuz toplumda bakım ile ilgili sorumlulukların öncelikle hastanın kızı, eşi ya da oğlunun eşine yüklenen sorumluluk olarak algılandığı görülmektedir. $\mathrm{Bu}$ nedenle kabul edilmiş ve üstlenilmiş ev ile ilgili sorumlulukların üstüne artmış hastalığa bağlı bakım yükü eklenince yaşanılan değișimin kötü yönde olması beklenilebilir bir sonuçtur. Diğer taraftan hastanın oğlu olan bakım vericilerin bakım verme ile ilgili deneyimlerinin olumlu olmasının; duygusal olarak ebeveynlere bakmak ile ilgili toplumun kendisine yüklediği beklentiyi yerine getirme rahatlı̆̆ından ya da evde eşinin özellikle fiziksel bakım sorumluluğunu kendisinin yerine karşılamasından kaynaklandığı düşünülebilir.

\section{Sonuç}

Bakım verme süreci fiziksel, duygusal ve psikolojik olarak bakım verene ve alana yük getiren bir süreçtir. Bu çalışmada bakım verenler genel olarak hasta bakımını üstlenmenin yaşamları üzerindeki değişimi “olumsuz" ve "değişmedi" olarak değerlendirmişlerdir.Çalışmada hastanın kanser tipi, cinsiyeti, yaşı (ileri yaş), eğitim düzeyi ve bakım verenin yaşı, eğitim düzeyi, çalışma durumu ve hasta ile yakınlık derecesinin bakım verme sürecinde yaşanandeğişimi artırdığı ortaya konmuştur.

\section{Kaynaklar}

1. Türkiye İstatistik Kurumu. "Sağlık Araştırması 2012". Erişim Yeri: http://www.tuik.gov.tr/Kitap.do?metod $=$ KitapDetay\&KT_ID=1\&KITAP_ID=223. Erişim Tarihi:20.02.2016.

2. Yancik R. Cancerburden in theaged. Cancer 1997;80:1273-1283.

3. Yancik $\mathrm{R}$, Ries LA. Cancer in olderpersons. Magnitude of the problem-how do weapplywhatweknow? Cancer1994;74:1995-2003.

4. Tuna H. Yaşlı onkolojik hastaya yaklaşım. İçinde: Beğer T, Dinçler DS, Altıparmak MR (eds.):Geriatrik Hasta ve Sorunları,İstanbul:ÏÜ Cerrahpașa Tıp Fakültesi Sürekli Tıp Eğitimi Etkinlikleri-Geriatrik Hasta ve Sorunları Sempozyumu, 2011:203-209.

5. Tuna S. Kanserli geriatrik hastalarda komorbidite ve klinik değerlendirme. Türk Onkoloji Dergisi 2007;22(4):192196.

6. Gorgulu U, Akdemir N. İleri evre kanser hastalarına bakım verenlerin yorgunluk ve uyku kalitesinin değerlendirilmesi.Genel Tıp Dergisi 2010;20(4):125-132. 
7. Erdem M. Yaşlıya bakım verme. Anadolu Hemşirelik ve Sağlık Bilimleri Dergisi 2008;11(4):101-106.

8. Stenberg U, Ruland CM, Miaskowski C. Review of theliterature on theeffects of caringfor a patientwithcancer. PsychoOncology2010;19:1013-1025.

9. Can T. Bakas bakım verme ölçeğinin Türkçeye uyarlanması, geçerlilik ve güvenirliliği. (Doktora Tezi), Uğur Çavlak, Denizli, 2010.

10. Tabachnick, L.S. Fidell. Using MultivariateStatistics (sixthed.) Pearson, Boston (2013).

11. Uğur Ö. Onkoloji hastasına evde bakım verenlerin bakım yükünün incelenmesi. (Yayınlanmamış Doktora Tezi), Çiçek Fadıloğlu,İzmir, 2006.

12. Francis LE, Kypriotakis G, O’Toole EE, Rose JH. Cancerpatientageandfamilycaregiverber eavementoutcomes. SupportiveCare in Cancer2016;24(9):3987-3996.

13. Nielsen $M K$, Neergaard $M A$, Jensen $A B$, Bro F, Guldin MB. Psychologicaldistress, health, andsocio-economicfactors in caregivers of terminallyillpatients: a nationwidepopulationbasedcohortstudy. SupportiveCare in Cancer 2016;24(7):3057-3067.

14. Çivi S, Kutlu R, Çelik HH. Depressionstatusandthefactorsaffecting thequality of life in therelatives of thepatientswithcancer.

GulhaneMedicalJournal 2011;53(4):248253.

15. Özlem U, Fadıloğlu ZÇ. Kanser hastasına bakım verenlere uygulanan planlı eğitimin bakım veren yükü üzerine etkisi. Cumhuriyet Hemşirelik Dergisi 2012;1(2):53-58.

16. Atagün Mİ, Balaban ÖD, Atagün $Z$, Elagöz M, Özpolat AY. Kronik hastalıklarda bakım veren yükü. Psikiyatride Güncel Yaklaşımlar2011;3(3):513-552.

17. Yildirim S, Engin E, Başkaya VA. İnmeli hastalara bakım verenlerin yükü ve yükü etkileyen faktörler. NöropsikiatriArsivi 2013;50(2):169-174.

18. Maguire R, Hanly P, Hyland P, Sharp L. Understandingburden in caregivers of colorectalcancersurvivors: what role do patientandcaregiverfactorsplay?

EuropeanJournal of CancerCare 2016;00:1-9.

19. KarabuğaYakar H, Pınar R. Kanserli hastalara bakım veren aile üyelerinin yaşam kalitesi ve yaşam kalitesini etkileyen faktörlerin değerlendirilmesi. Hemşirelikte Araştırma Geliştirme Dergisi2013;15(2):1-16.

20. Tang ST, Hsieh $\mathrm{CH}$, ChiangMC,at al.Impact of high self-perceivedburdentootherswithprefe rencesforend-of-life

careanditsdeterminantsforterminallyillc ancerpatients: prospectivecohortstudy.

Psycho-Oncology 2017;26(1):102-108.

21. Ge L, Mordiffi SZ. FactorsAssociatedwithhighercaregiverb urdenamongfamilycaregiversof elderlycancerpatients: A systematicreview. CancerNursing 2017;40(6):471-478.

22. Selçuk KT, Avcl D. Kronik hastalığa sahip yaşlılara bakım verenlerde bakım yükü ve etkileyen etmenler. SDÜ Sağlık Bilimleri Dergisi 2016;7(1):1-9. 